\title{
Tussen sciëntisme en fideïsme: Acceptatie van de evolutietheorie als theologische uitdaging
}

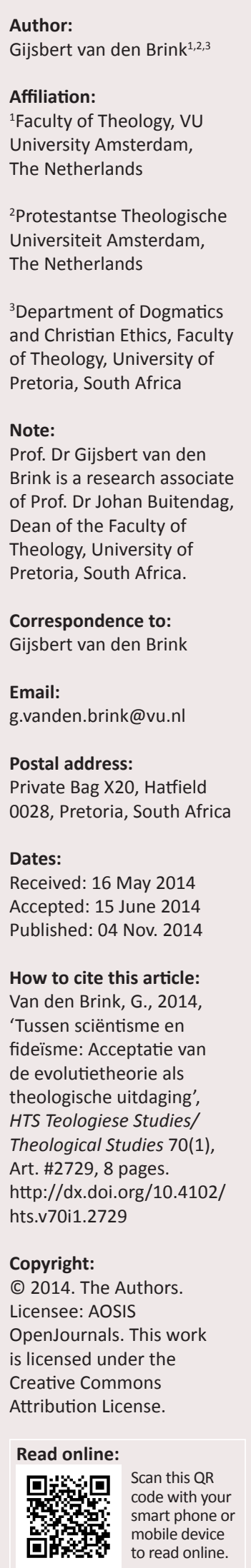

Between scientism and fideism: Acceptance of evolution as a theological challenge. In this contribution to the special issue of HTS Teologiese Studies/Theological Studies that is dedicated to Prof. Buitendag, I will explore what Prof. Buitendag's notion of a 'revised natural theology' might mean for the theological reception of the scientific theory of biological evolution. I argue that two extremes must be avoided here. One is the fideistic ignoring of (or refusal to take into account) the data that have been placed on the table regarding the evolutionary development of life on earth, as if these do not concern theology. The other extreme that theology must steer clear of is a scientistic over-interpretation of our knowledge of the evolutionary past, whereby the theory of evolution is magnified to a comprehensive philosophy of life ('evolutionism') that is incompatible with Christian faith.

\section{Inleiding}

Johan Buitendag heeft de dialoog tussen theologie en de natuurwetenschappen hoog in het vaandel staan. Er is hem veel aan gelegen dat de theologie niet naïef voorbijgaat aan wat vanuit andere wetenschapsgebieden aan data aan het licht wordt gebracht voor zover die gevolgen hebben voor een adequate doordenking van theologische thema's. Enige tijd geleden heeft hij zelfs gepleit voor een hernieuwde natuurlijke theologie, waarbij hij de huiver die in bepaalde protestantse kringen hiervoor bestaat te boven wil komen (Buitendag 2011:159). Het gaat hem daarbij om een gekwalificeerde of herziene natuurlijke theologie, waarbij niet zozeer (zoals in klassieke vormen van natuurlijke theologie) gezocht wordt naar bevestiging van het christelijk geloof vanuit de natuurlijke wereld, maar waarin het streven naar een coherente theologie wordt uitgebreid tot een groter geheel dat ook andere intellectuele velden omvat:

The time is ripe for us to be able to arrive once again in an accountable way at a qualified natural theology. Thanks to the contemporary dialogue with various other sciences, theology now has the opportunity to take this matter under review ... Where Systematic Theology asks for the intrinsic coherence of theology, a revised natural theology extends this coherency to theology and the intellectual world as a whole. (Buitendag 2011:159, 160)

In deze bijdrage aan dit aan Prof. Buitendag opgedragen nummer van HTS Teologiese Studies/ Theological Studies wil ik nagaan wat dit uitgangspunt betekent voor de theologische verwerking van de biologische evolutietheorie. Daarbij zullen we mijns inziens twee uitersten moeten vermijden. Het ene is een fideïstisch voorbijgaan aan alles wat aan gegevens over de evolutionaire ontwikkeling van het leven op aarde op tafel is gelegd, alsof dat de theologie niet zou regarderen. Het tweede uiterste dat de theologie moet vermijden, is een sciëntistisch over-interpreteren van onze kennis van het evolutionaire verleden, waarbij de evolutietheorie uitvergroot wordt tot een omvattende levensbeschouwing ('evolutionisme') die zich niet met het christelijk geloof laat verenigen.

Het is nog niet zo eenvoudig om hier de goede (midden)weg te vinden, omdat het debat, dat zeker in de Verenigde Staten en delen van West-Europa in alle heftigheid gevoerd blijft worden, vervuild is door bijdragen die levensbeschouwing en wetenschap niet helder van elkaar onderscheiden. Dan leidt ofwel de evolutiebiologie tot atheïsme, ofwel het christelijk geloof tot afwijzing van de evolutiebiologie. Daarnaast is er een veelheid aan evolutionaire theorieën die allerlei gevolgen (kunnen) hebben voor de theologie, maar waarvan nog volstrekt onduidelijk is of ze in wetenschappelijke kring zullen 'overleven' dan wel spoedig weer verlaten zullen worden. Te denken valt hier bijvoorbeeld aan de zeer uiteenlopende theorievorming die plaatsvindt in het nog jonge vakgebied van de cognitieve religiewetenschap (Cognitive Science of Religion, of kortweg CSR; vgl. bijv. Barrett 2011). Hier doet de theologie er goed aan geen overhaaste conclusies te trekken uit velden van onderzoek die nog volop in ontwikkeling zijn en waar nog weinig vast staat.

Dat roept de vraag op wat eigenlijk wél vast staat. Welke onderdelen, vooronderstellingen en implicaties van de evolutietheorie behoren tot wat men met W.B. Drees (2002:66) zou kunnen 
noemen 'consolidated knowledge', waarachter men dus niet meer terug kan en die theologen daarom ook niet moeten proberen te ontkennen of relativeren? In de volgende paragrafen wil ik uitwerken wat ik zie als de belangrijkste pijlers van de evolutietheorie, en aangeven waarom ik denk dat (ook orthodox-protestantse) theologen er niet goed aan doen deze in de natuurwetenschap nauwelijks omstreden inzichten te (blijven) aanvechten of relativeren. Het gaat om de volgende vier basale aannames, die tezamen de belangrijkste coördinaten van de orthodox-darwiniaanse variant van de evolutietheorie vormen. Alle vier deze aannames vinden we namelijk reeds terug in het werk van Charles Darwin:

1. De opvatting dat het proces van evolutie in hoge mate aangestuurd wordt door het principe van natuurlijke selectie op basis van toevallige mutaties. De 'ontdekking' van dit principe wordt gezien als Darwins belangrijkste bijdrage aan de doorbraak van de evolutietheorie.

2. De vooronderstelling dat dit proces van evolutie zich heeft afgespeeld op een geologische tijdschaal van vele miljoenen jaren, zodat het leven op aarde en meer nog de aarde zelf een duizelingwekkend hoge leeftijd heeft.

3. De zogeheten theorie van gemeenschappelijke afstamming (theory of common ancestry), ofwel de gedachte dat alle leven op aarde uiteindelijk teruggaat op één of hooguit enkele grondvormen, waaruit de diverse soorten geëvolueerd zijn.

4. De stelling dat in deze evolutionaire processen lijden (of althans wat we intuïtief als lijden aanmerken) en dood van meet af aan aanwezig geweest zijn en een onmisbare rol gespeeld hebben bij de voortgang van het leven. ${ }^{1}$

Het is niet zo dat deze aannames 'bewezen' zijn, maar wel is duidelijk dat ze stuk voor stuk hecht verankerd zijn in het hedendaagse wetenschappelijk onderzoek. Daarbij geldt dat ze onderling nauw met elkaar verbonden zijn, zodat het moeilijk is ze geheel van elkaar los te maken. Laten we ze niettemin voor de helderheid van elkaar onderscheiden en afzonderlijk nader bevragen op hun papieren.

\section{Natuurlijke selectie}

Dat evolutie (= doorontwikkeling) op basis van natuurlijke selectie verantwoordelijk is voor de wijze waarop soorten zich aan hun omgeving aanpassen, is in feite nauwelijks omstreden. Ook zij die aannames 2, 3 en 4 ontkennen of betwijfelen, onderschrijven doorgaans aanname 1 . Deze valt immers empirisch te toetsen en vindt daarbij keer op keer bevestiging. In talloze schoolboeken vindt men het voorbeeld van de berkenspanner, een mot waarvan een donkere en een lichtere, witachtige variant voorkomt. Voorafgaande aan de industriële revolutie domineerde in een stad als Liverpool de lichte variant, die een betere schutkleur had op de witte berken. Toen die berken als gevolg van de smog echter geleidelijk aan donkerder kleurden, kregen de zwarte berkenspanners de overhand, omdat predatoren hen minder gemakkelijk zagen. Men kan zich goed voorstellen dat als

\footnotetext{
1.Er zijn binnen het (darwiniaanse) evolutiemodel nog wel andere theorieën te onderscheiden die breed aanvaard raakten, bijvoorbeeld over de wijze waarop onderscheiden die breed aanvaard raakten, bijvoorbeeld over de wijze waarop
soorten ontstaan (zie Mayr 1991:36-37). Het gaat ons echter om die aannames en soorten ontstaan (zie Mayr 1991:36-37). Het gaat ons echter om
vooronderstellingen die theologisch het meest te denken geven.
}

zo'n veranderingsproces zich doorzet (wat in dit geval als gevolg van ingevoerde milieuwetgeving niet gebeurde) dit uiteindelijk leidt tot het uitsterven van de lichtere berkenspanners. Het is duidelijk wat hier gebeurt: onder invloed van een 'toevallige' verandering in de natuurlijke omgeving zijn exemplaren met bepaalde eigenschappen beter aangepast aan de gewijzigde omstandigheden dan andere. Daardoor overleven ze niet alleen vaker, maar zijn ze ook vaker in staat nageslacht te verwekken, dat dan vaak over dezelfde belangrijke eigenschap beschikt. Los van de vraag of je dit evolutie moet noemen, is duidelijk dat natuurlijke selectie hier een belangrijke rol speelt, evenals de survival of the fittest, dat wil zeggen het overleven van de best aangepaste organismen.

Sommigen beperken de strekking van dit soort processen echter tot één en dezelfde soort: het is volgens hen niet zo, dat op deze wijze ook het ontstaan van de diverse soorten verklaard kan worden, zoals Darwin dacht. De varianten binnen een soort zouden dus niet zozeer van elkaar kunnen gaan verschillen dat er geen onderlinge paring meer plaatsvindt, want dan zou de ene soort immers (naar een gangbare opvatting van het soortbegrip) in tweeën gesplitst zijn. Om deze gedachte goed af te bakenen van de overkoepelende these spreekt men wel over micro-evolutie, als onderscheiden van macro-evolutie. Micro-evolutie zou bovendien slechts aan de orde zijn in het huidige tijdsbestek, dat niet verder teruggaat dan een beperkt aantal millennia - om precies te zijn tot aan de zondeval van de mens in het paradijs. Daarvóór zou ze niet hebben plaatsgevonden, omdat dieren voorafgaand aan de zondeval nog niet stierven. Deze restricties bij aanname 1 zijn natuurlijk ingrijpend, en leveren een heel ander totaalplaatje op.

Toch is het van belang dat het basisprincipe waarop de evolutietheorie scharniert - natuurlijke selectie op basis van 'toevallige' mutaties ${ }^{2}$ - hetzelfde is. Met andere woorden: er is feitelijk niemand die dé grote ontdekking van Darwin ontkent. Het is dan ook onterecht dat het begrip evolutie bij bepaalde groepen christenen en andere theïsten weerzin of beduchtheid oproept, en met behulp van woordverbindingen als 'schepping of evolutie' in diskrediet wordt gebracht. Immers, bij nader doorvragen blijkt dat ook degenen die met een dergelijke slagzin werken wel degelijk onderschrijven dat schepping en evolutie samengaan. Anders gezegd: iedereen gelooft in evolutie, inclusief alle mechanismen van de strijd om overleving, geleidelijke aanpassing, et cetera, die daarbij horen. Alleen achten sommigen het veld waarop evolutie zich afspeelt beperkt in tijd en ruimte. De vraag is natuurlijk, of dat laatste terecht is. Dat brengt ons bij respectievelijk aannames 2 en 3 .

2.We schrijven 'toevallige' hier tussen hoge komma's, omdat dit woord ambigu is Het kan betekenen: onvoorspelbaar voor onderzoekers. Maar men kan er ook mee het kan betek bedoelen: toevallig op een manier die elke vorm van overkoepelende leiding of sturing uitsluit. Die laatste invulling zullon De hoge komma's bedoelen dan ook aa betekenis gaat die de strikt-wetenschappelijke is waarover overeenstemming bestaat. Voor een heldere bespreking van het verschil tussen beide zie Haarsma en Haarsma (2007:41-43) 


\section{De geologische tijdschaal}

De gedachte dat het leven op aarde al heel lang blootgesteld is aan processen van evolutie kon in feite pas doorbreken nadat geologen hadden vastgesteld dat de aarde en ons zonnestelsel veel ouder zijn dan in traditionele schattingen werd aangenomen. Wil evolutie namelijk als verklaring dienen voor de enorme variatie in (en binnen) soorten, dan vergt zij astronomisch veel tijd. Toen in de zeventiende eeuw de geologie tot ontwikkeling kwam, pasten geologen hun bevindingen in in een aan de Bijbel ontleend tijdschema: de aarde en haar gesteenten zouden enkele duizenden jaren oud zijn, en de wereldwijde zondvloed verklaarde de toen toch ook al vele - fossielen die aangetroffen werden. ${ }^{3}$ Fossielen van vissen die gevonden waren in hoge bergen, zouden daar bijvoorbeeld achtergelaten zijn toen het water van de zondvloed hoog stond. Toen in de achttiende eeuw het geologisch onderzoek een hogere vlucht nam, kwamen echter steeds meer gegevens boven tafel die zich moeilijk met deze gedachtengang lieten rijmen. Sommige gesedimenteerde aardlagen bleken bijvoorbeeld zo dik te zijn, dat ze onmogelijk konden zijn ontstaan door materiaal dat tijdens een eenjarige zondvloed was aangeslibd. En in Frankrijk werden onder grasland diverse lagen geharde lava aangetroffen, die wezen op evenzovele perioden van vulkanische activiteit - die er echter sinds mensenheugenis niet gemeld waren. Toen duidelijk werd dat er daar tussendoor nog aanzienlijke perioden van erosie door water moesten zijn geweest, ontstond het beeld van een grillige geschiedenis die niet meer in een paar duizend jaar past, zelfs niet wanneer men uitging van een wereldwijde zondvloed. ${ }^{4}$

Vooral het werk van Charles Lyell (1797-1875) zoals met name vastgelegd in zijn driedelige Principles of geology (1830-1833) werd in dit verband invloedrijk. Lyell ging er in zijn 'uniformitarisme' van uit dat allerlei veranderingen in aardlagen niet door plotselinge catastrofen tot stand waren gekomen, maar door uiterst geleidelijke processen die niet wezenlijk verschilden van hedendaagse processen. Die processen moesten dan dus al wel vele millennia aan de gang zijn. Inderdaad bleek een steeds grotere hoeveelheid waarnemingen niet goed verklaarbaar vanuit het 'zondvloedmodel', en ook niet uitsluitend vanuit allerlei locale overstromingen of catastrofes. Rond 1840 geloofden dan ook vrijwel alle geologen dat de aarde ten minste miljoenen jaren oud moest zijn, en dus al een lange geschiedenis achter de rug had voordat de mens op het toneel verscheen. Het is belangrijk hierbij aan te tekenen, dat de betreffende geologen geen atheïsten waren die erop uit waren om Genesis te ontkrachten. Lyell was bijvoorbeeld om godsdienstige redenen lange tijd gekant tegen de rol

\footnotetext{
3.Dit historisch gegeven laat zien dat het onterecht is om het creationisme als een laat-moderne uitvinding te beschouwen, zoals onder meer Cunningham (2010) en Van de Beek (2005) doen. Reeds in de zeventiende eeuw las men de eerste hoofdstukken van Genesis (behalve spiritueel óók) historisch, telde men de leeftijdsaanduidingen in de genealogieën bij elkaar op, et cetera. Daarbij moet natuurlijk wel bedacht worden dat er destijds geen alternatief verklaringsmodel voorhanden was waarbinnen de geologische bevindingen geplaatst konden worden.

4.Vergelijk voor het bovenstaande Haarsma en Haarsma (2007:87-89); Young en Stearley (2008:79-80, en meer in het algemeen $71-100$ voor de cruciale achttiende eeuw)
}

die Darwin in zijn evolutietheorie aan natuurlijke selectie toekende, en ook tegen de gedachte dat de mens uit het dierenrijk geëvolueerd zou zijn (Klaver 1997:xii-xiii). ${ }^{5}$ Ook had men niet per se een liberale visie op het gezag van de Bijbel:

Many started out with a firm commitment to interpret Genesis as literal accurate history ... If the rocks of the earth had been consistent with a young earth and global flood model, these scientists surely would have found it. Instead, the earth itself testified otherwise, over and over again. (Haarsma \& Haarsma 2007:89-90)

Dit riep natuurlijk toen al - dus al vóór Darwin - de vraag op, hoe deze waarnemingen verenigd konden worden met het gezag van de Bijbel. ${ }^{6}$ De spanningen rondom de interpretatie van Genesis en de ontwikkeling van de natuurwetenschap gaan dus aan Darwin vooraf.

Intussen is bekend dat Darwin het werk van Lyell verslonden heeft. Het eerste deel nam hij mee op de reis met de Beagle en gebruikte hij om zijn waarnemingen te interpreteren. Lyells uniformitarisme bracht Darwin tot zijn gradualisme, dat wil zeggen tot zijn opvatting dat het leven op aarde zich geleidelijk ontwikkeld had in de richting van steeds complexere levensvormen. De aarde zag hij daarbij als de klok van de evolutie: aan de opbouw van de aardlagen viel af te lezen in welke volgorde de diverse (sub) soorten waren ontstaan. Lyell op zijn beurt bewonderde Darwins werk zeer. Ook al maakte hij kerngedachten eruit - inclusief die van de toenemende complexiteit van het fossiele archief! - niet mee, Lyell was overtuigd van de theoretische kracht van Darwins werk en stimuleerde zelfs de publicatie van de Origin of Species (vgl. Goodman 2010:80-81). Het uniformitarisme, met inbegrip van de onlosmakelijk daaraan verbonden theorie van 'deep time' (d.w.z. een geologische tijdschaal die vele miljoenen jaren omvat) fungeerde dus als de noodzakelijke achtergrond waartegen Darwin zijn evolutietheorie kon ontwikkelen.

Aan het eind van negentiende eeuw zouden schattingen van de ouderdom van de aarde oplopen tot vele honderden miljoenen jaren, en na de ontwikkeling van radiometrische dateringsmethoden in de twintigste eeuw gaat men er momenteel algemeen van uit dat de aarde en ons zonnestelsel de duizelingwekkende leeftijd van zeker 4.5 miljard jaar hebben. Dat is dan nog maar een deel van de tijd dat het universum bestond waaruit ons zonnestelsel voortkwam: ongeveer 13.7 miljard jaar. De eerste sporen van primitief leven op aarde lijken ruim 3.5 miljard jaar oud (Fransen 2009:55, 63, 96). ${ }^{7}$ Maar gaat alle leven biologisch op dat ene ontstaanspunt terug? Die vraag brengt ons bij een derde pijler van de evolutietheorie.

\footnotetext{
5.Dit gegeven wordt te weinig verdisconteerd in de kritische tekening die Terry Mortenson (2004) van Lyell geeft.

6.Vergelijk hierover voor de Engelse context bijvoorbeeld Klaver (1997) en de klassieke studie van Gillispie ([1951] 1996). Voor de sterke en zwakke punten van dit laatste werk zie het 'Foreword' van Nicolaas A. Rupke in de heruitgave, v-xix. (Tot de zwakke punten behoort dat Gillisplie Lyell te kritiekloos volgde in diens suggestie dat de catastrofisten destijds wetenschappelijke amateurs waren.)

7.Opmerkelijk was overigens de ontdekking dat het universum er niet altijd is geweest maar op een bepaald moment, namelijk dat van de zogeheten oerknal (Big Bang), is ontstaan. Atheïstische kosmologen als Fred Hoyle hadden lange (Big Bang), is ontstaan. Atheïstische kosmologen als Fred Hoyle hadden lange
tijd grote moeite met deze visie, omdat ze zo wonderwel aansloot bij het joodschristelijk scheppingsgeloof.
} 


\section{Gemeenschappelijke afstamming}

In 1991 schreef de toonaangevende evolutiebioloog Ernst Mayr (1904-2005) dat ' ... there is probably no biologist left today who would question that all organisms now found on the earth have descended from a single origin of life' (Mayr 1991:24). Dat is ongetwijfeld een overdrijving. Toch is het opvallend dat natuurwetenschappers in het algemeen en biologen in het bijzonder sterk overtuigd zijn van de gemeenschappelijke afstamming van alle leven op aarde. Waar komt die sterke overtuiging vandaan? Ze hangt samen met het feit dat inzichten die onafhankelijk van elkaar verworven werden in uiteenlopende wetenschappelijke disciplines - zoals vergelijkende anatomie, geologie, biochemie, paleontologie en genetica - elkaar bleken te versterken. Ze suggereerden op verschillende manieren dat de diverse levensvormen op aarde op elkaar teruggaan en dus op een zeer complexe wijze uit elkaar moeten zijn voortgekomen (Fransen 2009:79-85; vgl. Haarsma \& Haarsma 2007:161-174). ${ }^{8}$

Zo maakte biochemisch onderzoek naar de mate van verschil tussen diverse organismen in termen van de volgorde van nucleotiden en typen aminozuren de reconstructie mogelijk van een 'moleculaire klok' van de evolutie, waarbij patronen van verwantschap en afsplitsing duidelijk werden (Pope 2007:193; vgl. Protero 2007:96-99). Het bleek namelijk dat moleculaire veranderingen zich in een tamelijk constante snelheid voltrekken, zodat uit de hoeveelheid moleculaire verschillen tussen twee soorten min of meer afgeleid kan worden hoe lang geleden ze globaal genomen 'uiteengingen'. De uitkomsten van zulk onderzoek bleken nauwkeuriger geijkt te kunnen worden aan de hand van analyses van fossielen, dat wil zeggen de afdrukken van dode planten en dieren in gesteenten. Door middel van diverse methoden, waaronder de beroemde koolstof- 14 methode, kan namelijk vastgesteld worden uit welke tijd de aardlagen waarin deze fossielen gevonden zijn dateren. Het opvallende daarbij is dat verschillende dateringsmethoden in principe dezelfde leeftijden opleveren. Rekenfouten of andersoortige vergissingen kunnen op deze wijze dan ook gecorrigeerd en uitgesloten worden (Fransen 2009:55-64). ${ }^{9}$

Maar wijst het fossiele materiaal wel op gemeenschappelijke afstamming? Vaak hoort men zeggen dat het allerlei 'gaten' kent: organismen waarvan men moet aannemen dat ze bestaan hebben omdat anders de overgang van de ene naar de andere levensvorm niet verklaard kan worden, maar die nog nooit zijn aangetroffen. Dat zou er dan op wijzen dat er juist diverse afstammingslijnen zijn, die niet allemaal op één punt teruggaan. Hier moet echter een drietal dingen bedacht worden. 1. Het ontbreken van allerlei levensvormen is niet zo verwonderlijk als men bedenkt dat de kans op fossilisering

8.Beide studies bieden in het algemeen zeer leesbare en leerzame overzichten van de stand van zaken rondom de evolutietheorie, waaraan ik in deze paragraaf het nodige ontleen.

9.Deze leeftijdsmetingen bleken maximaal zo'n 4.4 miljard jaar terug te gaan, een getal dat overeen bleek te komen met de leeftijdsbepalingen van meteorieten en maanstenen (Fransen 2009:62). Vandaar dus de gedachte dat ons zonnestelse ongeveer 4.4 miljard jaar oud moet zijn. van een plant of dier nogal klein is - en dan spreken we nog niet over de kans dat we zo'n fossiel vele millennia later terugvinden. 2. De laatste jaren zijn in snel tempo wel degelijk tot dusver onbekende levensvormen in fossiel materiaal aangetroffen, en dit proces gaat nog altijd door. Het gaat daarbij ook om organismen die tot de 'tussenvormen' behoord moeten hebben, zoals de in 2006 aangetroffen tiktaalik, een tussenvorm tussen vissen en gewervelde landdieren (Fransen 2009:83). ${ }^{10}$ Sommige daarvan waren reeds door evolutiewetenschappers voorspeld, inclusief de aardlagen waarin ze zich zouden moeten bevinden (Haarsma \& Haarsma 2007:164). 3. Verwonderlijk is niet zozeer hoeveel gaten er in het fossiele archief zitten, maar hoe precies het geordend is: sommige fossielen treft men alleen in oudere aardlagen aan; andere, zoals van de mens, alleen in jongere. Gefossiliseerde organismen worden globaal gesproken zelfs steeds complexer naarmate de aardlagen waarin ze aangetroffen worden jonger zijn. Claims van sceptici die stelden dat bijvoorbeeld menselijke fossielen in dezelfde aardlaag te vinden zouden zijn als fossiele resten van dino's, moesten weer ingetrokken worden. Kortom, hoewel verre van compleet, gaat van het fossiele archief toch de sterke suggestie uit dat de diverse soorten uit elkaar voortgekomen zijn, waarbij ze stap voor stap steeds complexer werden (Fransen 2009:79-85).

Deze hypothese kreeg een enorme bevestiging vanuit een geheel andere tak van wetenschap, namelijk de genetica. Deze nam in de eerste decennia van de twintigste eeuw een hoge vlucht (de term zelf werd gemunt in 1905), nadat het belang van het erfelijkheidsonderzoek van de DuitsTjechische monnik Gregor Mendel (1822-1884) duidelijk was geworden. Wetenschappers probeerden vast te stellen welke moleculen verantwoordelijk waren voor de overervingspatronen die Mendel bij bepaalde planten had vastgesteld, en die algemeen geldig leken te zijn. Dat leidde tot de ontdekking van chromosomen, genen en uiteindelijk (in 1944) van het DNA. Daarmee werd eindelijk duidelijk waar de oorsprong lag van de variatie in populaties waarnaar Darwin zo lang tevergeefs gezocht had: de moleculaire basis voor evolutionaire veranderingen bevond zich precies in dit DNA. Later onderzoek bracht aan het licht dat het genoom van soorten en typen meer op elkaar lijkt naarmate deze dichter bij elkaar staan: het totale DNA van diverse forellensoorten lijkt meer op elkaar dan op dat van andere vissen, de genetische patronen van vissen hebben meer met elkaar gemeen dan met die van zoogdieren, et cetera. Met name gedurende het afgelopen decennium is de beschikbare informatie over de genen van mensen, planten en dieren enorm toegenomen. Van de mens is inmiddels het complete genoom in kaart gebracht, gecodeerd in de vorm van ongeveer drie miljard letters. Vergelijking met het genoom van dieren laat zien dat de overeenkomsten heel groot zijn, en groter worden naarmate het dier 'dichterbij' staat. Wie bijvoorbeeld een willekeurig 10.Zie ook: Tiktaalik roseae, http://tiktaalik.uchicago.edu. 
stuk DNA van de mens neemt, heeft een kans van 98 procent dat eenzelfde segment ook bij chimpansees aan te treffen valt; en de 2 procent verschil geldt slechts voor zogenaamd niet-functioneel DNA (Fransen 2009:88-94).

Men zou natuurlijk kunnen zeggen dat de Schepper bij het creëren van alle soorten kennelijk gebruik heeft gemaakt van dezelfde bouwstenen. Maar de krachtige suggestie die van het genetische plaatje uitgaat is toch die van een fundamentele verwantschap tussen alle leven op aarde. Zo'n verwantschap lijkt ook sterk aanwezig tussen de mens en de andere primaten. Een en ander klopt ook goed met de bevindingen uit de genoemde andere takken van onderzoek, waarbij we bijvoorbeeld de vergelijkende anatomie en de biogeografie (die zich bezighoudt met de geografische verspreiding van de soorten, en onderzoekt waarom bijvoorbeeld kangoeroes vrijwel alleen in Australië voorkomen) nog buiten beschouwing lieten (vgl. Haarsma \& Haarsma 2007:165-167). Hetzelfde geldt voor de hedendaagse kosmologie, die laat zien hoezeer de geschiedenis van het ontstaan van en de ontwikkeling op onze planeet een geïntegreerd beeld vertoont.

Kortom, de evolutietheorie werd sterker dankzij de genetische revolutie. Was ze gedurende de eerste vijftig jaar nog aan veel twijfel en discussie onderhevig, met name over de aard van de mechanismen die haar voortdreven, sinds de zogeheten 'neo-darwiniaanse synthese' met de genetica zijn veel dingen nader uitgekristalliseerd. Dat verklaart ook waarom de gedachte van een gemeenschappelijke afstamming van alle leven zich haast onontkoombaar opdringt aan evolutie-onderzoekers en aan allen die hen 'narekenen'. Het is de veelheid van in dezelfde richting wijzende onderzoekslijnen die aan het evolutionaire verhaal een hoge mate van plausibiliteit geeft. Zoals paus Johannes Paulus II stelde: de convergentie (dus het samenkomen en in dezelfde richting wijzen) van de resultaten van werk dat in onderlinge onafhankelijkheid werd verricht - een convergentie die noch werd gezocht noch gefabriceerd - is op zichzelf een belangrijk argument ten gunste van de evolutietheorie. ${ }^{11}$

\section{Lijden, extinctie en dood}

Uit het voorgaande volgt onmiddellijk dat de geschiedenis van het leven op aarde boordevol is met lijden, uitsterven en dood. Immers, de processen die we vandaag de dag om ons heen in de natuur kunnen waarnemen moeten zich in min of meer dezelfde vormen al gedurende vele miljoenen jaren hebben afgespeeld. Altijd en overal geldt het basisprincipe: de een $z^{\prime} n$ dood is de ander $z^{\prime} n$ brood. De soorten en organismen - en volgens sommigen zelfs de genen - zijn verwikkeld in een onophoudelijke strijd om te overleven, en dat kan feitelijk alleen maar ten koste van elkaar. Daarbij

11."It is indeed remarkable that this theory has been progressively accepted by researchers following a series of discoveries in various fields of knowledge. The convergence, neither sought nor fabricated, of the results of work that was convergence, neither sought nor fabricated, of the results of work that was
conducted independently is in itself a significant argument in favor of this theory (Pope John Paul II 1996:351). zijn dieren naar we mogen aannemen weliswaar niet wreed in de zin dat ze elkaar net zoals mensen willens en wetens pijn kunnen aandoen. Maar het is ook bepaald niet zo dat het er allemaal zo waardig, snel en pijnloos mogelijk aan toe gaat. Dieren opereren slechts volgens het principe dat de maximalisering van hun eigen overlevingskansen en die van hun soort boven alles gaat, hoeveel dat andere organismen ook kost aan lijden en pijn.

Daarbij doen zich tal van taferelen voor die we intuïtief als wreed ervaren. Bekend is het voorbeeld van de parasitaire sluipwesp, die zijn eieren in of op een gastheer-insect plaatst. De larven groeien vervolgens door zich tegoed te doen aan de organen van deze gastheer, waarbij ze er nauwkeurig op toezien dat ze de vitale organen voor het laatst bewaren, zodat de gastheer zo lang mogelijk in leven blijft en diens organen dus vers voedsel blijven vormen. Langzaam maar zeker sterft het gastheer-insect zodoende een (naar we aannemen) pijnlijke dood. Bij slankapen in Noord-India leeft één mannetje vaak samen met meerdere vrouwtjes, bij wie hij nageslacht verwekt. Vaak komt er echter op enig moment een sterkere slankaap langs die zijn rol overneemt. Het eerste mannetje wordt dan in een celibataire rol gedwongen, waarna de veroveraar ertoe overgaat de nog niet gespeende kinderen die deze verwekte stuk voor stuk te doden. Als gevolg daarvan kunnen de zuigelingen geen melk meer afnemen bij hun moeders, zodat deze versneld weer gaan ovuleren en bronstig worden. De moordenaar van het kroost van zo'n moeder wordt vervolgens spoedig de vader van haar volgende kind (vgl. voor dit voorbeeld Williams 1997:156-157, die er retorisch aan toevoegt: 'Do you still think God is good?'; vgl. ook voor kritiek op deze conclusie Pope 2007:11).

Zo zijn er veel meer voorbeelden bekend van de uiterst geraffineerde wijze waarop het evolutieproces voortdurend slachtoffers maakt - waarbij uitsluitend het recht van de sterkste geldt. Van de tien vogeltjes die in een willekeurig voorjaar geboren worden, schijnen er in het najaar gemiddeld al negen opgevreten te zijn door andere dieren. En mutatis mutandis geldt hetzelfde voor allerlei andere dieren. De evolutie gaat gepaard met een enorme 'verspilling' van leven: alle organismen zijn er op uit zoveel mogelijk nageslacht te verwekken, want hoe meer kinderen je hebt hoe groter is de kans dat er enkelen van nog leven op het moment dat ze zelf vruchtbaar zijn en het leven weer door kunnen geven. Dat de overgrote meerderheid van het nageslacht het doorgaans niet haalt, is geen factor van belang. Moeder natuur staat onverschillig tegenover het lot van het wat zwakkere individu. Een zee van pijn - of daarmee vergelijkbare sensaties - doortrekt dan ook de dierenwereld. ${ }^{12}$ Lijden en dood lijken vanaf het onafzienbaar verre verleden waarin dierenleven ontstond ingebouwd in de dieptestructuur van het animale leven.

12.Sommigen vragen zich af of het niet antropomorf (en dus onjuist) is om in dit verband over 'pijn' te spreken. Doorgaans gaat men er echter van uit dat sensaties die vergelijkbaar zijn met menselijke fysieke pijn toch in elk geval voorkomen bij organismen die over een centraal zenuwstelsel beschikken. Bij soorten waar dat niet zo is, geldt mijns inziens dat het bij twijfel altijd beter is om aan te nemen dat er inderdaad van zoiets als fysieke pijn sprake kan zijn. Verhelderend over deze problematiek is Murray (2008). 
Dan hebben we het nog niet over het massaal voorkomen van uitsterving in de loop van de geschiedenis. Geschat wordt dat zeker 99 procent van de soorten die ooit op aarde geleefd hebben inmiddels uitgestorven zijn. Dat zijn dus onvoorstelbaar veel unieke soorten en schepselen, die normaal gesproken nooit meer op aarde zullen terugkeren. Het is dus allemaal veel erger dan we geneigd zijn te denken wanneer we op een mooie lentedag in het bos wandelen en de vogeltjes horen fluiten. Charles Darwin was zich van dit alles al zeer bewust. Het droeg naar men aanneemt ook bij aan de erosie van het christelijk geloof in zijn leven, met name van het geloof in een goede God die in alles voorziet. 'Wat een boek zou de kapelaan van de duivel kunnen schrijven over de onhandige, verspillende, blunderende, lage en afgrijslijk wrede werken van de natuur!', roept hij in een brief uit. ${ }^{13}$ Darwins tijdgenoot, Alfred Tennyson (18091892), voelde dit al even scherp aan toen hij in een beroemd geworden dichtregel sprak over nature red in tooth and claw - een natuur die bloedrood is door alles wat er gebeurt met tanden en klauwen (Tennyson [1969] 1989:399). Hoewel deze regel al in 1850 geschreven werd, dus enkele jaren voor de publicatie van Darwins Origin of Species, verwoordt ze een besef dat sindsdien onder invloed van de evolutietheorie alleen nog maar sterker is geworden. We leven in een wereld waarop zich reeds lang voor de mens op het toneel verscheen afschuwelijke taferelen moeten hebben afgespeeld.

Veel christenen zijn opgevoed in een latent-creationistische omgeving. Zonder dat het er nu zo dik bovenop lag, was er toch het geloof in een zesdaagse schepping, resulterend in een jonge, mooie aarde die als gevolg van de zonde van de mens degenereerde. Wanneer zij later gaandeweg echter in aanraking komen met de grote hoeveelheid aanwijzingen voor een miljoenen jaren lange evolutionaire ontwikkeling van het leven, gaat de knop soms snel om: dan geloven we vanaf nu toch in evolutie! Want dan is dat kennelijk de manier waarop God de soorten in het aanzijn heeft geroepen. Men doet alsof deze omschakeling niet veel om het lijf heeft en het geloof verder onaangetast laat. Maar dit vierde aspect van het evolutionaire proces laat zien dat het zó eenvoudig niet is. Juist hier roept de evolutietheorie immers grote theologische vragen op. Hoe verhoudt zich bijvoorbeeld deze zee van lijden, uitsterving en dood in de dierenwereld tot de goedheid en voorzienigheid van God, en tot de goedheid van de schepping? Dat zijn dus vragen die om grondige doordenking vragen (zie voor voorbeelden hiervan o.m. Murray 2008; Hoggard Creegan 2013; Southgate 2008;).

Het is intussen begrijpelijk dat veel gelovigen zich er niet zomaar van laten overtuigen dat zich al zovele miljoenen jaren zo'n 'wreed' evolutionair scenario op aarde heeft afgespeeld. Er is immers geen eenduidig en sluitend bewijs voor de evolutietheorie geleverd. Is het bovenstaande dan wel zo plausibel als aanhangers van de evolutietheorie het doen voorkomen? Wordt er niet te snel geëxtrapoleerd en gegeneraliseerd, mogelijkheden die misschien niet zo voor de hand liggen uitgesloten, en problemen gemakshalve weggewuifd of gerelativeerd? Dat laatste kan ook nog wel eens gebeuren, omdat men per se creationisten - of theïsten in het algemeen - niet in de kaart wil spelen. Dan zouden onderhuids dus ook levensbeschouwelijke impulsen een belangrijke rol spelen. Kan er, kort gezegd, niet sprake zijn van een tunnelvisie?

Het is terecht wanneer dit soort vragen gesteld worden. De wetenschapsgeschiedenis is vol met theorieën die ooit algemeen aanvaard werden, zelfs met een air van vanzelfsprekendheid (zoals de ethertheorie), maar die uiteindelijk toch niet bleken te kloppen. Wie zich daarvan bewust is, zal zich niet zo gauw uitleveren aan de wetenschappelijke waan van de dag, en zelfs niet aan die van de eeuw. Toch kan de evolutietheorie daar vandaag niet meer toe gerekend worden. Het is weliswaar nog altijd een wetenschappelijke theorie en niet meer dan dat - maar dan wel één in de orde van grootte van de zwaartekrachttheorie. Er is in elk geval onder actieve natuurwetenschappers vrijwel niemand meer die aan de juistheid en bruikbaarheid ervan twijfelt. Ze verklaart immers enorm veel verschijnselen die anders moeilijk te begrijpen zijn en onsamenhangend blijven. Ze doet dat zowel in de ogen van niet-christelijke als van christelijke natuurwetenschappers. En ze doet het bovendien in toenemende mate. We zagen in bovenstaande weergave al hoe de diverse hypothesen geleidelijk aan verdere bevestiging en versterking vonden, soms zelfs op voor iedereen verrassende wijze (zoals bij de ontdekking van het DNA). De evolutietheorie doet precies wat een wetenschappelijke theorie volgens hedendaagse wetenschapsfilosofen moet doen: op een elegante en in principe eenvoudige manier tal van waarnemingen met elkaar in verband brengen en verhelderen. Doordat ze dit in de ogen van de meeste deskundigen bovendien veel beter doet dan enig concurrerend model, geldt de evolutietheorie op zijn minst als zeer plausibel.

\section{Conclusie}

Dat wil echter niet zeggen dat de hier besproken kernen van de evolutietheorie kritiekloos geaccepteerd moeten worden. Er zijn inderdaad nog altijd onopgeloste problemen die niet onderschat moeten worden. En er zijn aspecten die empirisch minder hecht verankerd zijn dan andere. De aanwijzingen voor een geologische tijdschaal zijn inmiddels zo overweldigend, dat ze nog slechts door een kleine groep mensen (de jonge aarde creationisten) aangevochten worden. Maar de twijfels over de alomvattendheid van het mechanisme van natuurlijke selectie op basis van toevallige mutaties leven veel breder. ${ }^{14}$ Ook wordt steeds duidelijker dat behalve lijden en dood in de dierenwereld ook veel positieve waarden worden aangetroffen, zoals samenwerking, empathie, et cetera (zie bijv. Nowak \& Coakley 2013). Zeker van wetenschappers mag verwacht worden dat ze het in principe toejuichen wanneer men niet allerlei zaken op gezag van anderen overneemt, maar zich door middel van kritische toetsing een zelfstandig oordeel probeert te vormen.

14.Zie bijvoorbeeld het uitstekende boekje van Ronald Meester (2014). 
Bij alle openstaande vragen en doorgaande discussies lijkt de richting waarin het onderzoek zich ontwikkelt er intussen toch wel een te zijn van steeds verdere consensus over de wijze waarop evolutie werkt. Te midden van allerlei theorieën en speculaties lijkt het aandeel van wat genoemd wordt 'geconsolideerde kennis' gaandeweg groter te worden. Het materiaal dat wijst op evolutie in zoiets als de boven besproken zin wordt al met al steeds overtuigender. We kunnen daar dan ook niet zo makkelijk meer achter terug, veel minder makkelijk in elk geval dan ten tijde van Darwin, of zelfs ten tijde van iemand als Herman Bavinck, toen de evolutietheorie in een crisis verkeerde.

Maar zelfs als er wel een weg terug zou zijn, blijft nog altijd overeind staan dat onze westerse cultuur doordrenkt is van evolutionaire voorstellingen. Christenen die in die cultuur leven zullen zich er daarom op moeten bezinnen hoe ze omgaan met mensen die misschien wel openstaan voor het Evangelie, maar voor wie de evolutionaire ontwikkeling van het leven eenvoudigweg als een paal boven water staat. Hoe valt het Evangelie aan hen te communiceren? Impliceert christen-worden voor hen dat ze niet alleen Jezus Christus als Heer aanvaarden, maar ook afstand moeten doen van wat ze slechts kunnen zien als eenvoudige feitenkennis over de ontwikkeling van het leven op aarde? In elk geval moet men goed weten wat men doet wanneer men daar op grond van een reeks bijbelteksten op aandringt. Want zijn het wel die bijbelteksten die daartoe dwingen, of is het eerder een gevestigde uitleg daarvan - een uitleg die misschien betwistbaarder is dan we zelf doorhebben? Men laadt in elk geval een zware verantwoordelijkheid op zich wanneer men deze twee - het Evangelie en een eigen uitleg, invulling of aanvulling daarvan - met elkaar gelijkstelt.

De kerkvader Augustinus schreef in dit verband een scherp woord dat nog altijd veel te denken geeft:

Ook een niet-christen weet iets over de aarde ... de soorten dieren, heesters, stenen enzovoort, en deze kennis houdt hij voor zeker vanuit de rede en de ervaring. $\mathrm{Nu}$ is het een schandelijk en gevaarlijk iets wanneer een ongelovige een christen, die zogenaamd de betekenis van de Heilige Schrift uitlegt, onzin hoort praten over deze dingen ... Hoe zullen ze de boeken [van de Bijbel] gaan geloven als het gaat om zaken als de opstanding der doden, de hoop op het eeuwige leven en het Koninkrijk der hemelen, wanneer ze denken dat deze pagina's vol staan met onjuistheden over feiten die ze zelf geleerd hebben uit ervaring en het licht van de rede? (De Genesis ad litteram I.19, 39)

$\mathrm{Nu}$ is de evolutietheorie (c.q. de hier geschetste kern daarvan) niet zomaar een feit dat opkomt uit de ervaring en de rede. Maar het is wel de theorie die zoals we zagen veruit de meest plausibele interpretatie geeft van allerlei opvallende verschijnselen die als het ware om een verklaring roepen. De evolutietheorie levert zo'n verklaring bovendien op een relatief eenvoudige manier. Dat wil niet zeggen dat ze in de uitwerking niet enorm complex is; maar de basale principes die we boven bespraken, met name het principe van natuurlijke selectie op basis van 'toevallige' mutaties, geeft op een verrassende manier samenhang aan tal van afzonderlijke waarnemingen. Allerlei problemen die we anders over zouden houden, worden op een 'elegante' manier opgelost.

Daarbij zijn niet allerlei moeizame hulpconstructies nodig, zoals feitelijk het geval is bij het creationisme met zijn zondvloedgeologie of schijnleeftijdtheorie. Het is de afgelopen tijd steeds duidelijker geworden dat het creationisme zich in nogal wat bochten moet wringen om het eigen paradigma enigszins overeind te houden. Dat is een veeg teken. Het ptolemaeïsche wereldbeeld ging destijds ten onder doordat teveel epicykels ('bijcirkels') aangenomen moesten worden om de theorie in overeenstemming te houden met de banen die de planeten daadwerkelijk vertoonden. Wetenschapstheoretisch gezien verdient dan een eenvoudiger, elegantere interpretatie van de verschijnselen de voorkeur - niet omdat die 'bewezen' is, maar wel omdat ze een groter probleemoplossend vermogen heeft (vgl. Van den Brink 2004:60-88).

Anders ligt het met allerlei theorievorming die op zichzelf buitengewoon interessant is, maar tegelijk nog volop in discussie en beweging. Een voorbeeld (naast het al genoemde CSR-onderzoek) is de theorie dat seksualiteit van functie veranderde toen bipedalisme ontstond, dat wil zeggen toen de veronderstelde voorouders van de mens op twee benen begonnen te lopen (Sheets-Johnstone 1990:9198; vgl. Van Huyssteen 2010:331-334). De status en impact van dit soort theorieën moet zich nog uitkristalliseren, en het is ook de vraag hoezeer ze theologisch precies van belang zijn (dat wil dus zeggen: wat ze betekenen in verband met onze relatie tot God).

De theologie moet niet zomaar achter allerlei wetenschappelijke 'modes' aanlopen. Ze dient zich het bekende adagium van W.R. Inge aan te trekken, dat wie met de tijdgeest huwt doorgaans spoedig weduwe is. Maar er komt wel een moment, waarop ze zich niet langer kan onttrekken aan de verantwoordelijkheid zich rekenschap te geven van ontwikkelingen die niet zomaar een gril van de tijdgeest zijn, en ook niet zomaar als 'een list van satan' weggezet kunnen worden. Men kan natuurlijk lang discussiëren over de vraag wanneer zo'n moment precies is aangebroken, en er zal daarin onvermijdelijk ongelijktijdigheid bestaan tussen verschillende groepen christenen. De evolutietheorie is wat dat betreft echt een 'reizend probleem' (vgl. Paul 2006:184-208). Maar het moment waarop ook orthodoxe christenen zich niet langer aan serieuze bezinning erop kunnen onttrekken, is nu wel aangebroken. Natuurlijk denken ook zij al sinds de tijd van Darwin na over evolutie en over wat acceptatie daarvan theologisch eventueel zou betekenen. Achteraf gezien moeten we zelfs zeggen dat sommigen van hen (zoals Darwins tijdgenoot Asa Gray en de Princetoniaanse theoloog Benjamin Warfield) hun tijd daarin ver vooruit waren. Maar nu de aanwijzingen voor het evolutionaire scenario zich gedurende de laatste decennia steeds verder hebben opgestapeld, valt er aan een dergelijke theologische bezinning niet meer te ontkomen. Dat houdt de theologie overigens ook bij de les, en maakt dat ze nooit helemaal op de lauweren van de traditie kan rusten! 
Vrees voor theologische bezinning op dit terrein, hoe begrijpelijk misschien ook, is intussen niet nodig. Het mag immers duidelijk zijn dat zolang we de evolutietheorie maar zorgvuldig onderscheiden van het ideologisch geladen evolutionisme, deze de fundamenten van het christelijk geloof niet kan aantasten. Pas wanneer men aan de resultaten van wetenschappelijk onderzoek een levensbeschouwelijke status toekent, zoals welbewust gebeurt in wat tegenwoordig 'sciëntisme' genoemd wordt, ontstaan er grote problemen. Noodzakelijk is dit echter in genen dele. Het is zelfs niet op voorhand duidelijk waarom acceptatie van de evolutietheorie (als boven omschreven) niet samen zou kunnen gaan met een orthodoxe (zo men wil ook een orthodox-gereformeerde) invulling van het christelijk geloof, al is op dit terrein nog wel nader onderzoek gewenst. In Nederland ging de aanvaarding van evolutie onder christenen tot dusver vaak gepaard met, of werd zij gevolgd door, omarming van een meer vrijzinnige vorm van geloofsbeleving. De vraag is echter of er een noodzakelijk verband bestaat tussen die twee, dan wel dat het vooral sociaal-psychologische factoren waren die deze combinatie in de hand werkten - bijvoorbeeld doordat wie evolutie aanvaardde vanwege de vaak felle tegenstand van orthodoxe christenen eigenlijk min of meer als vanzelf in liberale richting opschoof.

Waar het voor vandaag op aankomt is in elk geval het zoeken naar een weg tussen fideïsme en sciëntisme, waarbij duidelijk wordt hoe de coherentie waar de theologie naar streeft ook in verband gebracht kan worden met kennisvelden zoals die zich de afgelopen tijd in de biologie en andere wetenschappen ontwikkeld hebben (vgl. Buitendag 2011:160).

\section{Tegenstrijdige belangen}

De auteur verklaart geen financiële of persoonlijke belangen te hebben die hem ongepast kunnen hebben beïnvloed bij het schrijven van dit artikel.

\section{Literatuurverwijzingen}

Barrett, J.L., 2011, Cognitive science, religion and theology: From human minds to divine minds, Templeton Press, West Conshohocken, PA.

Buitendag, J., 2009, 'Nature as creation from an eco-hermeneutical perspective: From a "natural theology" to a "theology of nature"', HTS Teologiese Studies/ Theological Studies 65(1), 509-518. http://dx.doi.org/10.4102/hts.v65i1.272

Buitendag, J., 2011, 'Van den Brom's concept of relationality as a prerequisite for a revised natural theology. A personal encounter', in Th. Boer, H.A.H. Maat, A Meesters \& J. Muis (reds.), Van God gesproken. Over religieuze taal en relationele theologie, pp. 159-174, Boekencentrum, Zoetermeer.
Cunningham, C., 2010, Darwin's pious idea: Why the ultra-darwinists and creationists both get it wrong, Eerdmans, Grand Rapids, MI.

Drees, W.B., 2002, Creation: From nothing until now, Routledge, London.

Fransen, R., 2009, Gevormd uit sterrenstof. Schepping, ontwerp en evolutie, Medema, Vaassen. http://dx.doi.org/10.1163/9789004247345

Gillispie, C.S., [1951] 1996, Genesis and geology: A study of the relations of scientific thought, natural theology, and social opinion in Great Britain, 1790-1850, Harvard University Press, Cambridge, MA.

Goodman, L.E., 2010, Creation and evolution, Routledge, London.

Haarsma, D.B. \& Haarsma, L.D., 2007, Origins: A Reformed look at creation, design, and evolution, Faith Alive, Grand Rapids, MI.

Hoggard Creegan, N., 2013, Animal suffering and the problem of evil, Oxford University Press, Oxford. http://dx.doi.org/10.1093/acprof:oso/9780199931842.001.0001

Klaver, J.M.I., 1997, Geology and religious sentiment: The effect of geological discoveries on English society and literature between 1829 and 1859, Brill, Leiden.

Mayr, E., 1991, One long argument: Charles Darwin and the genesis of modern evolutionary thought, Harvard University Press, Cambridge, MA.

Meester, R., 2014, Arrogant. Waarom wetenschappers vaak minder weten dan ze denken, Ten Have, Utrecht.

Mortenson, T., 2004, The great turning point: The church's catastrophic mistake on geology - before Darwin, Master Books, Green Forest, AR.

Murray, M.J., 2008, Nature red in tooth \& claw: Theism and the problem of animal suffering, Oxford University Press, Oxford. http://dx.doi.org/10.1093/acprof:oso/9780199237272.001.0001

Nowak, M.A. \& Coakley, S. (eds.), 2013, Evolution, games, and God: The principle of cooperation, Harvard University Press, Cambridge MA.

Paul, H., 2006, “'De historie heeft mij overmand”. Historiciteit als reizend probleem in het Nederlandse protestantisme', in G. van den Brink \& E. van Burg (reds.), Strijdbaar of lijdzaam: de positie van christenen in het publieke domein, pp. 184208, Groen, Heerenveen.

Pope John Paul II, 1996, 'Message to Pontifical Academy of Sciences on evolution', Origins 26, 351

Pope, S., 2007, Human evolution and Christian ethics, Cambridge University Press, Cambridge. http://dx.doi.org/10.1017/CBO9780511550935

Protero, D.R., 2007, Evolution: What the fossils say and why it matters, Columbia University Press, New York, NY.

Sheets-Johnstone, M., 1990, The roots of thinking, Temple University Press, Philadelphia, PA.

Southgate, C., 2008, The groaning of creation: God, evolution, and the problem of evil, Westminster John Knox Press, Louisville, KY.

Tennyson, A., Lord, [1969] 1989, 'In Memoriam A.H.H.', in C. Ricks (ed.), Tennyson: A selected edition, n.p., Longman, Harlow.

University of Cambridge, n.d., Darwin Correspondence Project, viewed 09 August 2014, from http://www.darwinproject.ac.uk

University of Chicago, n.d., Tiktaalik roseae, viewed 09 August 2014, from http://tiktaalik.uchicago.edu

Van de Beek, A., 2005, Toeval of schepping? Scheppingstheologie in de context van het moderne denken, Kok, Kampen.

Van den Brink, G., 2004, Een publieke zaak. Theologie tussen geloof en wetenschap, Boekencentrum, Zoetermeer.

Van den Brink, G. \& Van Burg, E. (eds.), 2006, Strijdbaar of lijdzaam: de positie van christenen in het publieke domein, Groen, Heerenveen.

Van Huyssteen, J.W., 2010, 'When were we persons? Why hominid evolution holds the key to embodied personhood', Neue Zeitschrift für Systematische Theologie und Religionsphilosophie 52, 331-334. http://dx.doi.org/10.1515/nzst.2010.021

Williams, G.C., 1997, The puny fish's glow, HarperCollins, New York, NY.

Young, D.A. \& Stearley, R.F., 2008, The Bible, rocks and time: Geological evidence for the age of the earth, InterVarsity Press, Downers Grove, IL. 